\title{
Harmonisasi Hukum sebagai Perlindungan Hukum oleh Negara bagi Para Pihak dalam Transaksi Elektronik Internasional
}

\author{
Abdul Halim Barkatullah \\ Fakultas Hukum Universitas Lambung Mangkurat \\ Jln. Brigjen H. Hasan Basry, Banjarmasin Kalsel 70123 \\ dr.halim_barkatullah@yahoo.co.id
}

\begin{abstract}
The main problems of this research are, first, why state intervention in the form of legal protection to relevant parties in international transaction is needed? Second, is legal harmonization able to become a solution in providing legal protection for relevant parties in electronic transactions? This research was a normative legal research. The research findings show that, first, the parties involved in international transactions in free trade era are in a very weak position. Legal protection to the rights of the parties in international transactions cannot be fulfilled by only one legal aspect, but by a set of legal system so that the rights of the parties involved in electronic international transactions can be maintained. Second, the state's roles in providing legal protection for the parties involved in electronic international transactions are by: (i) abolishing legal obstacles and issuing regulation for transactions; (ii) providing facilities in the form of regulation of legal protection for the parties involved in international transactions which are done by the parties themselves (self-regulation); and (iii) the parties should be cautious when being involved in international trade transaction.
\end{abstract}

Keywords: Harmonization, legal protection, electronic transaction

\begin{abstract}
Abstrak
Perkembangan transaksi elektronik tidak terlepas dari laju pertumbuhan internet, karena transaksi elektronik berjalan melalui jaringan internet. Praktik transaksi elektronik banyak menimbulkan permasalahan yang cenderung merugikan para pihak dalam transaksi internasional dan menimbulkan berbagai permasalahan hukum dalam melakukan transaksi elektronik. Adapun permasalahan dalam penelitian ini, pertama, mengapa diperlukan intervensi negara dalam bentuk perlindungan hukum bagi para pihak dalam transaksi internasional? Kedua, apakah harmonisasi hukum dapat menjadi solusi dalam pemberian perlindungan hukum bagi para pihak dalam transaksi elektronik? Penelitian ini merupakan penelitian yuridis normatif. Hasil penelitian menyimpulkan, pertama, para pihak dalam transaksi internasional di dalam era perdagangan bebas sangat lemah, maka perlindungan hukum terhadap hak-hak para pihak dalam transaksi internasional tidak dapat diberikan oleh satu aspek hukum saja, melainkan oleh suatu perangkat sistem hukum, agar para pihak dalam transaksi elektronik internasional dapat dilindungi hak-haknya. Kedua, peranan negara dalam memberikan perlindungan hukum bagi para pihak dalam transaksi elekronik internasional dengan cara: (1) Menghilangkan kendala-kendala hukum dan memberikan pengaturan dalam transaksi; (2) Memberikan fasilitas dalam bentuk pengaturan terhadap upaya perlindungan hukum bagi para pihak dalam transaksi internasional yang diberikan oleh pelaku usaha (self-regulation); dan (3) kehati-hatian para pihak dalam transaksi internasional sendiri dalam melakukan transaksi perdagangan. Dalam penyusunan aturan hukum oleh negara diperlukan adanya keseragaman dalam memberikan perlindungan hukum bagi para pihak dalam transaksi internasional di berbagai negara. Ada alternatif model pengaturan yang diberikan oleh negara, yakni: pertama, harmonisasi hukum, dan Kedua, standarisasi Internasional.
\end{abstract}

Kata kunci: Harmonisasi, perlindungan hukum, transaksi elektronik 


\section{Pendahuluan}

Teknologi yang diciptakan berkembang seiring dengan kebutuhan manusia untuk memudahkan hidup dari yang sebelumnya. ${ }^{1}$ Kegiatan teknologi informasi dapat dimanfaatkan sebagai sarana untuk saling berkomunikasi, dimanfaatkan untuk penyebaran dan pencarian data, dimanfaatkan untuk kegiatan belajar mengajar, dimanfaatkan untuk memberi pelayanan, dimanfaatkan untuk melakukan transaksi bisnis.

Sejarah umat manusia sering pula dikatakan sebagai sejarah perkembangan peralatan, atau sejarah perkembangan teknologi. Teknologi informasi telah mengubah cara-cara bertransaksi dan membuka peluang-peluang baru dalam melakukan transaksi bisnis. ${ }^{2}$ Di samping itu, perkembangan teknologi informasi telah menyebabkan dunia menjadi tanpa batas (borderless) dan menyebabkan perubahan sosial yang secara signifikan berlangsung demikian cepat. Teknologi informasi saat ini menjadi pedang bermata dua, karena selain memberikan kontribusi bagi peningkatan kesejahteraan, kemajuan dan peradaban manusia, sekaligus menjadi sarana efektif perbuatan melawan hukum. ${ }^{3}$

Dalam perspektif masa depan, dunia akan menjadi sebuah perkampungan besar, sehingga batas-batas negara menjadi sangat kabur. Sementara itu, ekonomi global $^{4}$ mengikuti logikanya sendiri. Dalam proses tersebut, dunia dimanfaatkan serta terjadi intensifikasi kesadaran terhadap dunia sebagai satu kesatuan utuh. Namun demikian, proses globalisasi yang memungkinkan adanya arus informasi bebas hambatan melalui internet, peningkatan lalu lintas arus barang dan personalia secara internasional serta keanggotaan di dalam berbagai organisasi dunia, secara potensial memunculkan persoalan-persoalan hukum yang berdampak bagi masyarakat, yang mau tidak mau harus ditangani oleh para ahli

${ }^{1}$ Hikmahanto Juwana, Hukum Ekonomi dan Hukum Internasional, Lentara Hati, Jakarta, 2002, hlm. 23.

2 Haris Faulidi Asnawi, Transaksi Bisnis transaksi elektronik Perspektif Islam, Magistra Insania Press, Yagyakarta, 2004, hlm. 42. hlm. 1.

3 Ahmad M. Ramli, Cyber Law dan HAKI dalam Sistem Hukum Indonesia, Refika Aditama, Bandung, 2004,

${ }^{4}$ Lance Castles, Politic dan Economic Behavior in Java: The Kudus Cigarette Industry, diterjemahkan oleh J. Sirait, Th. Sinar Harapan, Jakarta, 2006, hlm. 87. 
hukum. ${ }^{5}$ Berbagai permasalahan yang dimunculkan oleh teknologi informasi dan harus dihadapi oleh hukum semestinya telah cukup jelas dan dapat diduga. ${ }^{6}$

Perkembangan transaksi elektronik tidak terlepas dari laju pertumbuhan internet karena transaksi elektronik berjalan melalui jaringan internet. Pertumbuhan pengguna internet yang sedemikian pesatnya merupakan suatu kenyataan yang membuat internet menjadi salah satu media yang efektif bagi pelaku usaha untuk memperkenalkan dan menjual barang atau jasa ke calon para pihak dalam transaksi internasional dari seluruh dunia. transaksi elektronik merupakan model bisnis modern yang non-face (tidak menghadirkan pelaku bisnis secara fisik) dan non-sign (tidak memakai tanda tangan asli). ${ }^{7}$ Hadirnya transaksi elektronik memungkinkan terciptanya persaingan yang sehat antara pelaku usaha kecil, menengah, dan besar dalam merebut pangsa pasar. ${ }^{8}$

Praktik transaksi elektronik banyak menimbulkan permasalahanpermasalahan yang cenderung merugikan para pihak dalam transaksi internasional dan menimbulkan berbagai permasalahan hukum dalam melakukan transaksi elektronik. Transaksi jual beli transaksi elektronik juga merupakan suatu kontrak jual beli yang sama dengan jual beli konvensional yang biasa dilakukan masyarakat. Perbedaannya hanya pada media yang digunakan. Pada transaksi elektronik, media yang dipergunakan adalah media elektronik yaitu internet. Sehingga kesepakatan ataupun kontrak yang tercipta adalah melalui online.

Hampir sama dengan kontrak jual beli pada umumnya, kontrak jual beli online tersebut juga terdiri dari penawaran dan penerimaan. Sebab suatu kesepakatan selalu diawali dengan adanya penawaran oleh salah satu pihak dan penerimaan oleh pihak yang lain. ${ }^{9}$

Dalam transaksi elektronik persoalan mengenai siapa yang menanggung risiko bila terjadi, hal-hal sebagai berikut: (1) pesan yang curang, tidak sah atau diubah; dan (2) kesalahan dalam komunikasi yang disebabkan oleh perantara atau

\footnotetext{
${ }^{5}$ E.K.M. Masinambow, ed., Hukum dan Kemajemukan Budaya, Sumbangan Karangan Untuk Menyambut Hari Ulang Tahun ke-70 Prof. Dr. T.O. Ihromi, Yayasan Obor Indonesia, Jakarta, 2008, hlm. 3.

${ }^{6}$ David Bainbridge, Introduction to Computer Law, $3^{\text {nd }}$ Edition, Pitman Publishing, Landon, 2006, hlm. 1.

${ }^{7}$ Niniek Suparni, Masalah Cyberspace Problematika Hukum dan Antisipasi Pengaturannya Fortun Mandiri Karya,, Jakarta, 2001, hlm. 33.

${ }^{8}$ Farizal F. Kamal, Cyber business, cet. 3, Elex Media Komputindo, Jakarta, 2009, hlm. 1.

${ }^{9}$ Ibid., hlm. 228.
} 
masalah teknologi (misalnya server mati dan masalah jaringan). Meskipun masalah-masalah penipuan, integritas dan kesalahan bukan hal baru atau khusus bagi media elektronik, teknologi ini memunculkan hambatan unik yang membutuhkan penyelesaian inovatif. ${ }^{10}$

Ketika melakukan kontrak secara elektronik, dalam hukum penting untuk mengetahui identitas sebenarnya dari para pihak dalam transaksi internasional. Seorang pengguna dapat dengan mudah menggunakan nama samaran dalam transaksi elektronik. Seseorang juga dapat mengirimkan pesan elektronik, dan menjadikannya seperti berasal dari orang lain.

Bagi para pihak dalam transaksi internasional yang ingin melakukan transaksi elektronik, muncul dua masalah utama: (1) bagaimana para pihak dalam transaksi internasional dapat yakin bahwa orang yang diajak berkomunikasi tersebut adalah orang yang dimaksud? (2) dapatkah seorang peniru (bukan pelaku usaha sebenarnya) mengikat para pihak dalam transaksi internasional pada kontrak elektronik?

Dengan karakteristik transaksi elektronik tersebut, para pihak dalam transaksi internasional akan menghadapi berbagai persoalan hukum. Peraturan perundang-undangan yang berkaitan dengan perlindungan hukum bagi para pihak dalam transaksi internasional yang ada sekarang belum mampu melindungi para pihak dalam transaksi internasional dalam transaksi elektronik lintas negara. Dalam transaksi elektronik tidak ada lagi batas negara, maka undang-undang perlindungan hukum bagi para pihak dalam transaksi internasional masingmasing negara, seperti yang dimiliki Indonesia tidak akan cukup membantu, karena transaksi elektronik beroperasi secara lintas batas (bonder less).

Apabila transaksi elektronik tersebut berlangsung di antara pihak-pihak khususnya perorangan, yang merupakan penduduk dua negara yang berbeda, maka akan timbul masalah dalam penyelesaian sengketa, apakah dilakukan dengan penerapan hukum negara Tergugat atau berdasarkan hukum negara Penggugat atau apakah seyogyanya didasarkan kepada negara Pelaku usaha atau apakah didasarkan hukum negara dari para pihak dalam transaksi internasional.

${ }^{10}$ Saami Zain, "Regulation of E-Commerce by Contract: is it Fair to Consumers?", The University of West Los Angeles (2007), 31 U. West. L.A. L. Rev. 163, hlm. 176. 
Demikian pula mengenai pilihan pengadilan atau suatu badan arbitrase yang akan memeriksa sengketa tersebut, apabila para pihak dalam transaksi internasional tidak menentukan pilihan pengadilan atau suatu badan arbitrase terlebih dahulu, maka akan menjadi masalah jika timbul sengketa. ${ }^{11}$

\section{Rumusan Masalah}

Berdasarkan latar belakang masalah tersebut, maka yang menjadi pokok permasalahan, adalah sebagai berikut: pertama, mengapa diperlukan intervensi negara dalam bentuk perlindungan hukum bagi para pihak dalam transaksi internasional? Kedua, apakah harmonisasi hukum dapat menjadi solusi dalam pemberian perlindungan hukum bagi para pihak dalam transaksi elektronik?

\section{Tujuan Penelitian}

Berdasarkan permasalahan yang telah dirumuskan di atas, maka penelitian ini bertujuan untuk menguraikan dan menganalisis: pertama, urgensi intervensi negara dalam bentuk perlindungan hukum bagi para pihak dalam transaksi internasional. Kedua, harmonisasi hukum dapat menjadi solusi dalam pemberian perlindungan hukum bagi para pihak dalam transaksi elektronik.

\section{Metode Penelitian}

Penelitian mengenai perlindungan hukum oleh negara bagi para pihak dalam transaksi elektronik internasional merupakan jenis penelitian hukum ${ }^{12}$ normatif, yaitu penelitian yang mengacu kepada peraturan perundang-undangan yang berlaku baik di Indonesia maupun konvensi internasional. Penelitian ini dapat pula disebut sebagai penelitian doktrinal ${ }^{13}$ karena peneliti berusaha menemukan prinsip-prinsip yang berkaitan dengan permasalahan yang diteliti.

\footnotetext{
11 Ibid., hlm. 25.

12 Soerjono Soekanto dan Sri Mamudji, Penelitian Hukum Normatif, Rajawali Presss, Jakarta, 2004, hlm. 13.

${ }^{13}$ Bambang Sunggono, Metode Penelitian Hukum, Rajawali Press, Jakarta, 2007, hlm. 83.
} 
Untuk menjawab permasalahan yang ada, peneliti melakukan pengumpulan bahan hukum melalui studi dokumen (studi kepustakaan) meliputi bahan hukum primer, bahan hukum sekunder dan bahan hukum tersier yakni dengan cara melakukan inventarisasi dan diidentifikasi terhadap sejumlah peraturan perundang-undangan, konvensi-konvensi internasional, dokumen hukum, catatan hukum, hasil-hasil karya ilmiah dan bahan bacaan/literatur yang berasal dari ilmu pengetahuan hukum dalam bentuk buku, artikel, jurnal dan hasil penelitian yang ada kaitannya dengan penelitian ini.

Bahan hukum yang terkumpul kemudian diolah. Analisis yang digunakan dalam penelitian ini adalah metode kualitatif. Teknik analisis dilakukan secara interpretasi, yaitu bahan hukum diinterpretasikan dan dijabarkan dengan mendasarkan pada suatu norma-norma dan teori-teori ilmu hukum yang berlaku, sehingga pengambilan keputusan yang menyimpang seminimal mungkin dapat dihindari. Dengan menarik kesimpulan dengan mempergunakan metode penalaran secara induktif yaitu suatu pemikiran secara sistematis dari khusus ke umum, dan deduktif ialah suatu pemikiran secara sistematis dari umum ke khusus.

\section{Hasil Penelitian dan Pembahasan}

\section{Urgensi Intervensi Negara untuk Memberikan Perlindungan Hukum dalam Transaksi Elekronik}

Transaksi elektronik mengubah cara para pihak dalam transaksi internasional. Dengan bantuan internet, bisnis transaksi elektronik menembus batas-batas dan memberi para pihak dalam transaksi internasional akses yang lebih besar pada barang dan jasa dengan harga yang lebih murah. Persaingan perdagangan yang ketat telah memberi para pihak dalam transaksi internasional keuntungan dalam transaksi online, terutama dalam mendapatkan produk barang dan jasa. ${ }^{14}$

Kemudahan dalam melakukan belanja lewat internet, dengan berbagai fasilitas serta mekanisme transaksi elektronik, tidak membuat posisi tawar para

\footnotetext{
${ }^{14}$ Yun Zhao, Dispute Resolution in Electronic Commerce, Martinus Nijhoff Publishers, Leiden/Boston, 2009, hlm.
} 
pihak dalam transaksi internasional transaksi elektronik semakin membaik. Hal itu terlihat dari banyaknya indikasi yang memperlihatkan bahwa hak-hak perlindungan dan pengamanan bagi para pihak dalam transaksi internasional yang didapatkan sebelumnya di "ruang-nyata" dalam transaksi elektronik semakin berkurang, hingga merugikan para pihak dalam transaksi internasional di internet (yakni dalam ruang-maya). ${ }^{15}$ Misalnya, jika ada kekurangjelasan pada alamat tujuan pelaku usaha, atau jika barang atau jasa yang diberikan tidak memadai. para pihak dalam transaksi internasional cenderung lebih dirugikan oleh transaksi lewat internet dibanding jika dilakukan dalam transaksi di "ruang-nyata". 16

Hubungan pelaku usaha dengan para pihak dalam transaksi internasional dalam transaksi elektronik lintas negara, merupakan hubungan kontraktual. Transaksi elektronik lebih ditujukan dalam lingkup transaksi yang dilakukan secara elektronik dengan memadukan jaringan (networking) dari sistem informasi berbasiskan komputer (computer-based information system) dengan sistem komunikasi didasarkan atas jaringan dan jasa telekomonikasi (telecommunication-based), yang selanjutnya difasilitasi oleh keberadaan jaringan komputer global internet. ${ }^{17}$

Para pihak dalam transaksi internasional dalam transaksi elektronik tidak secara langsung berhadapan dengan pelaku usaha dalam pembelian barang atau menyewa layanan secara online. Hal ini dapat mengakibatkan risiko barang yang dikirimkan rusak, tidak dikirimkan, kurangnya layanan dan penipuan lain terhadap para pihak dalam transaksi internasional menjadi meningkat. Setelah barang dibeli secara online dari pasar transaksi elektronik dan kemudian dikirimkan, para pihak dalam transaksi elektronik internasional tidak dapat menelitinya seperti di "dunia nyata".18 Karena itu, ketersediaan informasi yang

15 Sekretaris Perdagangan AS William Daley dalam laporannya menyatakan bahwa pelanggaran privasi dan pelayanan yang kurang memadai merupakan bidang yang mendapat perhatian serius bagai sebagian besar para pihak dalam transaksi internasional. Roberta Furger, "Online Sales Up, Consumer Satisfaction Down”, PC W orld, 5 Februari 1999 (tersedia di http://www.pcworld.com/ pcwtoday/article/0,1510,9641.html). Diakses tanggal 3 Maret 2015.

16 Sebagaimana dikemukakan salah seorang penulis, "Persoalan para pihak dalam transaksi internasional di internet kian meningkat, dinilai dari jumlah keluhan para pihak dalam transaksi internasional yang dirangkum oleh National Association of Consumer Agency Administration dan organisasi nirlaba Consumer Federation of America." Tom Spring, 'What Happens When transaksi elektronik Goes Wrong? PC World, 18 Desember 1998 (tersedia di http://www.pcworld.com/pcwtoday/article/0,1510,9641.html). Diakses 4 Juni 2014.

${ }^{17}$ Edmon Makarim, Kompilasi Hukum Telematika, PT Raja Grafindo Persada, Jakarta, 2009, hlm. 319.

18 Rachelle Andrews, "Electronic Commerce: Lessons Learned From The European Legal Model", Intellectual Property Law Bulletin Spring (2005), 9 No. 2, hlm. 83. 
benar dan akurat mengenai para pihak dalam transaksi internasional dan pelaku usaha dalam transaksi elektronik merupakan suatu prasyarat mutlak. ${ }^{19}$

Dalam transaksi elektronik, apabila para pihak dalam transaksi internasional merasa tidak puas dengan produk yang dibeli dari pelaku usaha dan dengan identitas yang gampang disembunyikan di dunia online, maka sulit bagi para pihak dalam transaksi internasional mendapat pembayaran kembali (refund) dan mencari jalan penyelesaian masalah dari pada pelaku usaha. Persoalanpersoalan ini mengakibatkan para pihak dalam transaksi internasional bisa kehilangan kepercayaan pada dunia online. ${ }^{20}$

Seiring dengan keuntungan potensial transaksi elektronik juga melahirkan ketidakpastian dan berbagai risiko. Sifat-sifat yang menjadikan transaksi elektronik menguntungkan juga menciptakan risiko yang mengurangi kepercayaan para pihak dalam transaksi internasional. Dengan menggunakan, pelaku usaha dapat menempatkan diri mereka "di luar jangkauan yurisdiksi negara, yang mengakibatkan meningkatnya praktik pemasaran yang tidak fair, produk-produk yang tidak aman, metode pembayaran yang tidak aman, dan hilangnya privasi pribadi". Agar pasar elektronik internasional maju dan berkembang, maka risiko keamanan para pihak dalam transaksi internasional harus dihilangkan atau paling tidak diminimalisir. ${ }^{21}$

Berhubungan dengan itu, mengingat tujuan negara untuk menjaga dan memelihara tata tertib, diharapkan negara memberi perhatian. Perhatian negara terhadap hukum perlindungan para pihak dalam transaksi internasional ini, dinamakan politik hukum negara. ${ }^{22}$

Pentingnya suatu negara mengatur perlindungan hukum terhadap para pihak dalam transaksi internasional, umumnya didasarkan pada pertimbangan aktualitas dan urgensinya. Dalam pertimbangan aktualitasnya, perlindungan hukum bagi para pihak dalam transaksi internasional perlu ditegakkan pada sebuah pemerintahan berdasarkan rumusan situasi yang sedang dan akan berkembang terhadap "nasib"

${ }^{19}$ Yusuf Shofie, Perlindungan para Pihak dalam Transaksi Internasional dan Instrumen-instrumen Hukumnya, PT. Citra Aditya Bakti, Bandung, 2003, hlm. 10.

20 Rachelle Andrews, Loc. Cit.

21 Karen Alboukrek, "Adapting to A New world of transaksi elektronik: The Need for Uniform Consumer Protection in the International Electronic Marketplace”, George Washington International Law Review, 2003, hlm. 433.

22 Soediman Kartohadiprodjo, Tata Hukum di Indonesia, Cetakan ke-12, Ghalia Indonesia, Jakarta, 1993, hlm. 37. 
masyarakat para pihak dalam transaksi internasional. Pertimbangan ini biasanya ditempuh dengan memperhatikan:23 1 . tingkat pembangunan masing-masing negara; 2. pertumbuhan industri dan teknologi; 3. filosofi dan kebijakan pembangunan.

Dalam memberikan perlindungan hukum bagi para pihak dalam transaksi internasional dengan cara intervensi negara untuk melindungi hak-hak para pihak dalam transaksi internasional dalam bentuk peraturan perundang-undangan. Terhadap posisi tawar para pihak dalam transaksi internasional yang lemah tersebut, maka ia harus dilindungi oleh hukum. Hal itu dikarenakan salah satu sifat, sekaligus tujuan hukum adalah memberikan perlindungan (pengayoman) kepada masyarakat.24 Perlindungan hukum kepada masyarakat tersebut harus diwujudkan dalam bentuk kepastian hukum yang menjadi hak para pihak dalam transaksi internasional. ${ }^{25}$

Mengingat peran penting ini dan kenyataan bahwa para pihak dalam transaksi internasional biasanya individu dan dalam posisi yang lemah, maka perlu diberikan kepada mereka perlindungan hukum yang cukup. Kebijakan perlindungan hukum bagi para pihak dalam transaksi internasional akan mendorong kepercayaan para pihak dalam transaksi internasional sehingga memajukan partisipasi mereka dalam transaksi dan meningkatkan bisnis. ${ }^{26}$

\section{Pengaturan Hukum di Indonesia dalam Transasi Elektronik}

Sejak tahun 2008 telah diundangkannya Undang-Undang Nomor 11 Tahun 2008 tentang Informasi dan Transaksi Elektronik (UU ITE). Berlakunya UU ITE secara substantif mengatur mengenai keabsahan dari informasi elektronik, dokumen dan tanda tangan elektronik Pasal 5 bahwa: (1) Informasi Elektronik dan/atau Dokumen Elektronik dan/atau hasil cetaknya merupakan alat bukti hukum yang sah. (2) Informasi Elektronik dan/atau Dokumen Elektronik dan/atau hasil cetaknya sebagaimana dimaksud pada ayat (1) merupakan perluasan dari alat bukti yang sah sesuai dengan Hukum Acara yang berlaku di Indonesia. (3) Informasi Elektronik dan/atau Dokumen Elektronik dinyatakan sah

${ }^{23}$ Ibid., hlm. 21.

${ }^{24}$ Shidarta, Shidarta, Hukum Perlindungan Konsumen Indonesia, Edisi Revisi Grasindo, Jakarta, 2010, hlm. 112.

${ }^{25}$ Edmon Makarim, Op. Cit., hlm. 316.

${ }^{26}$ Yun Zhao, Op. Cit., hlm. 68. 
apabila menggunakan Sistem Elektronik sesuai dengan ketentuan yang diatur dalam Undang-Undang ini. (4) Ketentuan mengenai Informasi Elektronik dan/atau Dokumen Elektronik sebagaimana dimaksud pada ayat (1) tidak berlaku untuk: a. Surat yang menurut Undang-Undang harus dibuat dalam bentuk tertulis; dan b. Surat beserta dokumennya yang menurut Undang-Undang harus dibuat dalam bentuk akta notarial atau akta yang dibuat oleh pejabat pembuat akta.

Pembentuk UU ITE telah mempertimbangkan secara mendalam sebagaimana yang dinyatakan dalam bagian Penjelasan umum alinea kesebelas menyatakan bahwa ${ }^{27}$ secara yuridis kegiatan pada ruang siber tidak dapat didekati dengan ukuran dan kualifikasi hukum konvensional saja sebab jika cara ini yang ditempuh akan terlalu banyak kesulitan dan yang lolos dari pemberlakuan hukum. Kegiatan dalam ruang siber adalah kegiatan virtual yang berdampak sangat nyata meskipun alat buktinya bersifat elektronik. Dengan demikian, subjek pelaku harus dikualifikasikan pula sebagai orang yang telah melakukan perbuatan hukum secara nyata. Dalam kegiatan transaksi elektronik antara lain dikenal adanya dokumen elektronik yang kedudukannya disetarakan dengan dokumen yang dibuat di atas kertas.

Dalam kaitannya dengan tanggung jawab pelaku usaha tersebut, UU ITE telah mengaturnya secara tegas, yang dalam Pasal 9 ditentukan: Pelaku usaha yang menawar produk melalui Sistem Elektronik harus menyediakan informasi yang lengkap dan benar berkaitan dengan syarat kontrak, produsen dan produk yang ditawarkan. Lalu, dalam penjelasannya dijelaskan bahwa: yang dimaksud dengan "informasi yang lengkap dan benar" meliputi: a. Informasi yang memuat identitas serta status subjek hukum dan kompetensinya, baik sebagai produsen, pemasok, penyelenggara maupun perantara; $b$. Informasi lain yang menjelaskan hal tertentu yang menjadi syarat sahnya perjanjian serta menjelaskan barang dan/atau jasa yang ditawarkan, seperti nama, alamat, dan deskripsi barang/jasa.

Pasal 10 UU ITE menyebutkan: (1) setiap pelaku usaha yang menyelenggarakan transaksi elektronik dapat disertifikasi oleh Lembaga Sertifikasi Keandalan. (2) ketentuan mengenai pembentukan Lembaga Sertifikasi Keandalan tersebut akan diatur dengan Peraturan Pemerintah (PP).

${ }^{27}$ Lihat dalam Penjelasan Umum Undang-Undang Nomor 11 Tahun 2008. 
Atas dasar isi ketentuan Pasal 9 dan 10 beserta penjelasannya dapat dikemukakan bahwa pelaku usaha bertanggung jawab atas segala data dan dokumen yang telah diinformasikan melalui jaringan informasi elektronik secara lengkap dan benar serta patut dipercaya keakuratan dan kehandalanya. Hal tersebut dimaksudkan supaya dapat memberikan gambaran yang jelas mengenai subjek hukumnya, yang berkenaan dengan identitas pelaku usaha, status pelaku usaha, jenis usahanya, dan kompetensinya dalam usaha tersebut apakah sebagai produsen, pemasuk, perantara atau penyelenggara.

Pasal 11 UU ITE menyebutkan, bahwa: (1) Tanda Tangan Elektronik memiliki kekuatan hukum dan akibat hukum yang sah selama memenuhi persyaratan sebagai berikut: a. data pembuatan Tanda Tangan Elektronik terkait hanya kepada Penanda Tangan; b. data pembuatan Tanda Tangan Elektronik pada saat proses penandatanganan elektronik hanya berada dalam kuasa Penanda Tangan; c. segala perubahan terhadap Tanda Tangan Elektronik yang terjadi setelah waktu penandatanganan dapat diketahui; $d$. segala perubahan terhadap Informasi Elektronik yang terkait dengan Tanda Tangan Elektronik tersebut setelah waktu penandatanganan dapat diketahui; e. terdapat cara tertentu yang dipakai untuk mengidentifikasi siapa Penandatangannya; dan f. terdapat cara tertentu untuk menunjukkan bahwa Penanda Tangan telah memberikan persetujuan terhadap Informasi Elektronik yang terkait. (2) Ketentuan lebih lanjut tentang Tanda Tangan Elektronik sebagaimana dimaksud pada ayat (1) diatur dengan Peraturan Pemerintah. Pasal 12 UU ITE menyatakan bahwa :

(1) Setiap Orang yang melakukan pelanggaran ketentuan yang terkait dengan Tanda Tangan Elektronik, bertanggung jawab atas segala kerugian dan konsekuensi hukum yang timbul.

(2) Pengamanan Tanda Tangan Elekronik sebagaimana dimaksud pada ayat (1) sekurang-kurangnya:

a. Sistem tidak dapat diakses oleh orang lain yang tidak berhak.

b. Penanda Tanganan harus menerapkan prinsip kehati-hatian untuk menghindari penggunaan secara tidak sah terhadap data terkait pembuatan Tanda Tangan Elektronik.

c. Penanda Tanganan harus tanpa menunda-nunda, menggunakan cara yang dianjurkan oleh Penyelenggara Tanda Tangan Elektronik atau pun cara lain yang layak dan sepantasnya harus segera memberitahukan kepada seseorang yang Penanda Tangan Elektronik dianggap mempercayai Tanda Tangan Elektronik atau kepada pihak pendukung layanan Tanda Tangan Elektronik jika: 
1. Penanda tangan mengetahui bahwa data pembuat Tanda Tangan Elektronik telah dibobol, atau;

2. Keadaan yang diketahui oleh Penanda Tangan dapat menimbulkan resiko yang berarti, kemungkinan akibat bobolnya data pembuatan Tanda Tangan Elektronik, dan;

d. Dalam hal Sertifikat Elektronik digunakan untuk mendukung Tanda Tangan Elektronik, Penanda Tangan harus memastikan kebenaran dan keutuhan semua informasi yang terkait dengan Sertifikat Elektronik tersebut.

(3) Setiap orang yang melakukan pelanggaran ketentuan sebagaimana dimaksud pada ayat (1), bertanggungjawab atas segala kerugian dan konsekuensi hukum yang timbul.

Permasalahan yang berkenaan dengan tanggung jawab para penyelenggara sistem informasi erlektronik sebagai suatu hal yang tidak dapat dipisahkan dari urusan yang berkenaan dengan transaksi elektronik seperti transaksi elektronik dan EBusiness. Kelancaran lalu-lintas transaksi perdagangan secara elektronik itu sangat ditentukan oleh sampai sejauh mana penyelenggara sistem informasi elektronik tersebut menjalankan tugasnya secara profesional, jujur dan bertanggung jawab.

Dalam kaitannya dengan pengaturan mengenai hak dan kewajiban atau tanggung jawab penyelenggaraan sertifikasi, Sertifikasi Elektronik dan Sistem Elektronik tersebut telah diatur dalam UU ITE, yang mana dalam Pasal 13 menyatakan bahwa:

(1) Setiap Orang berhak menggunakan jasa Penyelenggara Sertifikasi Elektronik untuk pembuatan Tanda Tangan Elektronik.

(2) Penyelenggara Sertifikasi Elektronik harus memastikan keterkaitan suatu Tanda Tangan Elektronik dengan pemiliknya.

(3) Penyelenggara Sertifikasi Elektronik terdiri atas:

a. Penyelenggara Sertifikasi Elektronik Indonesia; dan

b. Penyelenggara elektronik asing.

(4) Penyelenggara Sertifikasi Elektronik Indonesia berbadan hukum Indonesia dan berdomisili di Indonesia.

(5) Penyelenggara Sertifikasi Elektronik asing yang beroperasi di Indonesia harus terdaftar di Indonesia.

(6) Ketentuan lebih lanjut mengenai Penyelenggara Sertifikasi Elektronik sebagaimana dimaksud pada ayat (3) diatur dengan Peraturan Pemerintah (PP).

Demikian pula dalam Pasal 14 ditentukan bahwa Penyelenggara Sertifikasi Elektronik sebagaimana dimaksud dalam Pasal 13 ayat (1) sampai dengan ayat (5) 
harus menyediakan informasi yang akurat, jelas, dan pasti kepada setiap pengguna jasa.

Setiap transaksi atau kontrak, apa pun bentuk dan jenis atau sifatnya akan mengalami berbagai persoalan atau konflik yang menimbulkan sengketa hukum. Sengketa hukum adalah suatu peristiwa yang terjadi dalam masyarakat yang membawa atau menimbulkan akibat hukum bagi para pihak dalam transaksi internasional. Implikasi yang dimaksud dalam penelitian ini adalah implikasi hukum, yang berarti suatu keterkaitan dan keterlibatan sistem hukum transaksi perdagangan elektronik internasional dalam mempengaruhi pembentukan dan penegakkan hukum di Indonesia.

Indonesia sebagai salah satu bagian dari masyarakat dunia internasional, tentunya tidak terlepas dari pergaulan hidup di dunia internasional. Demikian pula dalam kaitannya dalam proses pembentukan dan penegakkan hukum, apalagi yang berkenaan dengan transaksi perdagangan secara elektronik melalui berbagai jaringan internet yang bersifat trans-nasional serta daya kerjanya telah melampaui sekat-sekat dan batas-batas dari setiap negara.

\section{Bentuk Perlindungan yang Ditawarkan dari Organisasi Internasional}

Sejumlah institusi internasional menyusun dan menyatakan tanggapan masing-masing, terhadap kian meluasnya dan kian besarnya dampak internet dan transaksi elektronik. Kontribusi institusi internasional sangat berpengaruh terhadap pola peraturan "dunia maya" yang tengah berkembang.

Badan utama PBB meliputi General Assembly, Security Council, Secretariat, International Court of Justice, dan Economic and Social Council. Selain itu, ada sejumlah komisi, komite, kelompok kerja, dan badan-badan tambahan lainnya. Di antaranya adalah UN Commission on International Trade Law dan UN Conference on Trade and Development. 28

United Nations Commission on International Trade Law (UNCITRAL) bertugas memajukan perkembangan hukum perdagangan internasional. Badan ini telah menyusun draft UN Convention on Contracts for International Sale of Goods, dan

${ }^{28}$ Gerald R. Ferrera, et.al., Cyber Law Text and Cases, Thomson Learning, United States, 2010, hlm. 334. 
persetujuan internasional antara lain UNCITRAL Model Law on International Credit Transfer, dan UNCITRAL Model Law on Electronic Commerce. ${ }^{29}$

United Nations Conference on Trade and Development (UNCTAD) adalah perwakilan utama Majelis Umum PBB yang bertanggungjawab pada perdagangan dan pembangunan. Pada 1998, Majelis Umum (General Assembly) memberi dana khusus pada UNCTAD guna meningkatkan dan mengembangkan transaksi elektronik. Setelah itu, UNCTAD membentuk Electronic Commerce Section yang melaksanakan workshop guna membantu negara-negara berkembang memperluas bidang transaksi elektronik. ${ }^{30}$

Pedoman perlindungan para pihak dalam transaksi internasional secara umum diatur dalam Guidelines for Consumer Protection of 1985, yang dikeluarkan oleh PBB menyatakan: "para pihak dalam transaksi internasional di manapun mereka berada, dari segala bangsa, mempunyai hak-hak dasar sosialnya". Maksud hak-hak dasar tersebut adalah hak untuk mendapatkan informasi yang jelas, benar, dan jujur; Hak untuk mendapatkan ganti rugi; hak untuk mendapatkan kebutuhan dasar manusia (cukup pangan dan papan); Hak untuk mendapatkan lingkungan yang baik dan bersih serta kewajiban untuk menjaga lingkungan; dan hak untuk mendapatkan pendidikan dasar. PBB menghimbau seluruh anggotanya untuk memberlakukan hak-hak para pihak dalam transaksi internasional tersebut di negaranya masing-masing. ${ }^{31}$

Dibentuknya Model Law The United Nations Commission on International Trade Law (UNCITRAL) Model Law ${ }^{32}$ adalah untuk penyatuan hukum internet substantif, walaupun Model Law ini belum memberikan perlindungan hukum yang kompehensif bagi para pihak dalam transaksi internasional lintas batas, karena Model Law hanya memberikan perlindungan bagi para pihak dalam transaksi internasional tentang keabsahan transaksi dan tanda tangan digital (digital signature), namun Model Law ini menyajikan langkah awal terhadap penyatuan substantif hukum internet pada skala global.

\footnotetext{
${ }^{29}$ Ibid.

${ }^{30}$ Ibid.

31 Tini Hadad, Dalam AZ. Nasution, Hukum Perlindungan Konsumen, Diadit Media, Jakarta, 2006, hlm. vii.

${ }^{32}$ Model Law ini ditanda tangani pada acara sesi ke 15 Mejelis Umum PBB - New York, 28 Mei - 14 Juni 1996, diuraikan oleh The United Nations Commission on International Trade Law (UNCITRAL).
} 
Dalam penyusunan dan penetapan UNCITRAL Model Law mengenai transaksi elektronik, UNCITRAL menyadari betul, bahwa Model Law itu akan menjadi peranti yang lebih efektif bagi negara-negara yang memodernisir undangundang mereka, untuk membantu mereka merumuskan peraturan dalam transaksi elektronik dengan menggunakan Model Law. Pedoman itu guna memberikan panduan bagi negara-negara yang memberlakukan draft Model Law. Informasi yang disajikan dalam Pedoman ini dimaksudkan untuk menjelaskan mengapa ketentuan dalam Model Law dimasukkan sebagai ciri dasar dari peranti undangundang yang dirancang untuk mencapai tujuan Model Law. ${ }^{33}$

UNCITRAL sejak 1996 menyusun Draft Uniform Rules on Electronic Signatures $^{34}$ untuk membahas persoalan-persoalan seperti pembuktian dan sertifikasi, alokasi risiko dan pertanggungjawaban di antara berbagai pihak juga proses dan institusi yang mungkin diperlukan. Model Law tersebut juga mengatur tentang penawaran dan permintaan secara online. Perihal persyaratan perjanjian ditentukan bahwa perjanjian harus bersifat jelas, terbuka, dan transparan karena para pihak dalam transaksi internasional dalam perjanjian persebut berasal dari negara yang berbeda-beda dengan pengaturan hukum yang berbeda pula. Apabila tidak diatur secara jelas, terbuka, dan transparan nantinya dapat menimbulkan persoalan mengenai pilihan hukum yang menjadi acuan atau pedoman dalam penyelesian sengketa yang kemungkinan akan timbul. ${ }^{35}$

Upaya untuk membahas persoalan-persoalan hukum yang relevan dengan transaksi elektronik dilakukan Model Law The United Nations Commission on International Trade Law. Model Law tersebut ditujukan untuk meningkatkan posisi hukum dari transaksi elektronik dengan menghilangkan kendala hukum transaksi elektronik. Model Law itu tidak disusun dengan berpijak pada pihak manapun dalam transaksi elektronik, kecuali jika ketentuan-ketentuannya secara khusus dimasukkan dengan mengacu kepada kesepakatan mitra dagang atau kesepakatan yang lain dan Model Law juga mengatur tentang tanda tangan digital. ${ }^{36}$

$$
76 .
$$

${ }^{33}$ Abdul Halim Barkatullah, Transaksi Konsumen dalam Bisnis e-Commerce, Nusa Media, Bandung, 2009, hlm.

34 Tersedia di http://www.uncitral.org/en-index.htm; diakses pada 31 Agustus 2014.

35 Irna Nurhayati \& Dina Widyaputri Kariodimedjo, "Tantangan Transaksi Elektronik Bagi Hukum Bisnis Nasional", Mimbar Hukum Majalah FH UGM, Edisi Khusus No. 39/X/2001, hlm. 73.

36 Abdul Halim Barkatullah, Op. Cit., hlm. 77. 
Salah satu institusi yang paling aktif memusatkan perhatian pada persoalanpersoalan transaksi elektronik internasional adalah Organization for Economic Co-operation and Development (OECD). OEDC adalah suatu institusi konsultatif yang membantu negara-negara anggotanya untuk memajukan pertumbuhan ekonomi, pekerjaan, dan standar hidup melalui koordinasi hukum, regulasi dan kebijakan mereka. Kedua puluh sembilan negara anggotanya adalah negara yang memiliki perekonomian maju, sehingga seringkali disebut "perkumpulan negara-negara kaya". ${ }^{7}$ Sejak 1997, OECD telah menyelenggarakan konferensi tahunan tentang transaksi elektronik yang bertujuan mengembangkan Pedoman Perlindungan para pihak dalam transaksi internasional (Guidelines on Consumer Protection), dan juga aturan-aturan dasar perpajakan dan pelaku usaha elektronik. ${ }^{38}$

Negara-negara anggota OECD mengakui perlunya pendekatan yang terkoordinir internasional untuk menangani persoalan penyelesaian sengketa dalam transaksi elektronik. Dalam satu dokumen penting yang dirumuskan oleh OECD, Guidelines for Consumer Protection in the Context of Electronic Commerce, pedoman untuk perlindungan para pihak dalam transaksi internasional dalam penyelesaian sengketa dan ganti rugi bertujuan untuk melindungi para pihak dalam transaksi internasional yang terlibat dalam transaksi elektronik tanpa menghambat perdagangan. ${ }^{39}$

Pedoman ini berfungsi sebagai rekomendasi bagi pemerintah, pelaku usaha, para pihak dalam transaksi internasional dan perwakilan para pihak dalam transaksi internasional pada karakteristik perlindungan hukum bagi para pihak dalam transaksi internasional yang efektif untuk transaksi elektronik. Pemikiran yang mendasarinya, yaitu: pertama, hukum dan yurisdiksi yang dapat diterapkan dipilih untuk pengubahan yang tepat. Tidak ada rumusan mendetail dari applicable law atau prinsip yurisdiksi, tetapi pedoman ini mendeskripsikan keistimewaan perubahan yang tepat. Keadilan (fairness) adalah salah satu faktor terpenting dalam merealisasikan perlindungan hukum bagi para pihak dalam transaksi

${ }^{37}$ Ke 29 anggotanya adalah: Australia, Austria, Belgia, Kanada, Republik Czech, Denmark, Finlandia, Perancis, Jerman, Yunani, Hongaria, Islandia, Irlandia, Itali, Jepang, Korea, Luxemburg, Meksiko, Belanda, Selandia Baru, Norwegia, Polandia, Spanyol, Swedia, Swiss, Turki, Inggris, dan Amerika Serikat.

${ }^{38}$ Laporan, OECD Forum on Electronic Commerce, Oktober 1999, di www.oecd.org/dsti/sti/it/ ec/act/pdf/forum_report.pdf. diakses 4 Agustus 2001.

${ }^{39}$ Yun Zhao, Op. Cit., hlm. 86. 
internasional. Tujuan keadilan ini adalah memberi para pihak dalam transaksi internasional tingkat perlindungan yang tidak kurang dari yang diberikan dalam bentuk perniagaan lain dan memberi para pihak dalam transaksi internasional akses yang bermanfaat pada penyelesaian sengketa yang adil dan tepat waktu, serta ganti rugi tanpa biaya atau beban yang tak semestinya. ${ }^{40}$

Awal 1998, OECD merekomendasikan bahwa "tingkat perlindungan sama yang diberikan oleh hukum dan praktik yang diterapkan pada bentuk perniagaan lain harus diberikan pada para pihak dalam transaksi internasional yang berpartisipasi dalam kegiatan perdagangan melalui penggunaan jaringan global". Perlindungan hukum bagi para pihak dalam transaksi internasional tidak hanya penting bagi para pihak dalam transaksi internasional dalam transaksi, tetapi juga vital bagi perkembangan transaksi elektronik. ${ }^{41}$

Pada 1999, OECD mengadopsi seperangkat pedoman berkaitan dengan "perlindungan hukum bagi para pihak dalam transaksi internasional dalam konteks transaksi elektronik." Pedoman-pedoman OECD itu, seperti rangka untuk perdagangan global dan elektronik, mempromosikan self-regulation pelaku usaha dan kepemimpinan sektor swasta dalam menggunakan teknologi sebagai sebuah alat untuk melindungi dan memberdayakan para para pihak dalam transaksi internasional. Pedoman-pedoman itu mencakup kebijakan-kebijakan umum untuk mempromosikan keadilan dalam bisnis, pemasaran dan periklanan. Pedoman OECD, menyatakan bahwa pelaku usaha transaksi elektronik yang memasarkan produk pada para para pihak dalam transaksi internasional, sebaiknya memberikan informasi yang mudah diakses dalam memperkenalkan pelaku usaha, termasuk lokasi geografisnya, dan menginformasikan pada para pihak dalam transaksi internasional tentang setiap regulasi pelaku usaha, pensertifikatan, atau institusi penyelesaian sengketa yang relevan dengan transaksi itu. ${ }^{42}$

OECD bukan badan yang mengatur secara global. Pedoman yang dikembangkan oleh OECD ini tidak mengikat aturan-aturan di negara manapun. Pedoman ini hanya bertindak sebagai saran tentang apa yang dianggap kasus

\footnotetext{
${ }^{40}$ Ibid., hlm. 29.

${ }^{41}$ Ibid., hlm. 69.

${ }^{42}$ Ibid.
} 
bisnis yang fair dalam transaksi elektronik internasional. Namun, pedoman ini menjalankan dua tujuan utama. Pedoman ini bertindak sebagai skema pengatur, di mana pemerintah dapat meniru dalam pembuatan dan implementasi hukum perlindungan para pihak dalam transaksi internasional mengenai transaksi elektronik dan bagi pelaku usaha untuk berusaha sesuai perkembangan praktik selfregulatory-nya. Selain itu, pedoman ini membantu pelaku usaha pelaku untuk mendidik para pihak dalam transaksi internasional tentang praktik bisnis di internet. $^{43}$

OECD Guidelines dalam memberikan perlindungan hukum lebih menitik beratkan pada self regulation. OECD Guidelines mempromosikan self-regulation pelaku usaha dan kepemimpinan sektor swasta dalam menggunakan teknologi sebagai sebuah alat untuk melindungi dan memberdayakan para pihak dalam transaksi internasional, dengan mengurangi peran pemerintah untuk memberikan perlindungan hukum bagi para pihak dalam transaksi internasional. Disinilah letak permasalahan perlindungan hukum dalam OECD Guidelines. Perlindungan hukum bagi para pihak dalam transaksi internasional tidak bisa lepas dari peran pemerintah sebagai penggerak dari berbagai upaya untuk memberikan perlindungan hukum bagi para pihak dalam transaksi internasional baik upaya perlindungan hukum oleh pelaku usaha (self regulation), maupun oleh para pihak dalam transaksi internasional sendiri.

\section{Harmonisasi Hukum sebagai Solusi dalam Pemberian Perlindungan Hukum bagi Para Pihak dalam Transaksi Elektronik}

Peranan negara yang dapat dilakukan bagi para pihak dalam transaksi elektronik internasional dengan cara: (1) menghilangkan kendala-kendala hukum dan memberikan pengaturan dalam transaksi; (2) memberikan fasilitas dalam bentuk pengaturan terhadap upaya perlindungan hukum bagi para pihak dalam transaksi internasional yang diberikan oleh pelaku usaha (self-regulation); dan (3) para pihak dalam transaksi elektronik internasional sendiri.

${ }^{43}$ Abdul Halim Barkatullah, Op. Cit., hlm. 79. 
Peranan negara yang dimaksud di sini mencakup aspek nasional dan internasional. Artinya, tuntutan adanya kepastian hukum dalam melakukan transaksi dari segi aspek hukum nasional melalui pembentukan peraturan di bidang perlindungan hukum bagi para pihak dalam transaksi internasional, maupun aspek hukum internasional melalui perjanjian internasional, atau harmonisasi hukum.

Sifat internasional yang melekat pada jaringan digital dan teknologi komputer yang mencakup pasar elektronik, memerlukan pendekatan global terhadap perlindungan hukum bagi para pihak dalam transaksi elektronik internasional sebagai bagian dari kerangka hukum. Lingkungan jaringan global menantang kemampuan tiap negara, atau yurisdiksi untuk membahas persoalan yang berkaitan dengan perlindungan hukum bagi para pihak dalam transaksi internasional dalam konteks transaksi elektronik. Dengan demikian persoalan perlindungan hukum bagi para pihak dalam transaksi internasional ini dapat dibahas secara efektif, melalui konsultasi dan kerja sama internasional.

Diperlukan adanya keseragaman dalam memberikan perlindungan hukum bagi para pihak dalam transaksi internasional di berbagai negara. Ada alternatif model pengaturan yang diberikan oleh negara, yakni: Pertama, harmonisasi hukum, sistem transaksi elektronik yang beroperasi bukan hanya dalam yurisdiksi nasional suatu negara, juga diluar yurisdiksi negara tersebut. Namun, para para pihak dalam transaksi internasional yang terlibat dalam transaksi elektronik masih tetap terikat oleh hukum nasionalnya.

Dalam konteks ini, harmonisasi hukum merupakan solusi mutlak, hal ini dimaksudkan sebagai wahana untuk menciptakan seperangkat aturan yang prinsip-prinsip dasarnya berasal dari hukum nasional masing-masing negara. Dengan demikian masing-masing negara tidak akan merasa kehilangan kontrol terhadap aktivitas warganegaranya. Model harmonisasi seperti ini tidak akan mengabaikan eksistensi masing-masing hukum nasional, tetapi akan menyerap prinsip-prinsip dasar yang kemudian eksistensinya dipelihara lewat konsensus dan prinsip untuk memperoleh keuntungan bersama.

Kedua, Standarisasi Internasional. Model pengaturan lewat standarisasi internasional ini dapat dijadikan alternatif lain apabila partisipasi dan kerjasama 
antar negara sulit dicapai. Model pengaturan ini dengan menjadikan mutu dan kualitas pelaku usaha sebagai parameter utama tanpa adanya partisipasi langsung dari negara.

Negara harus membenahi peraturan perundang-undangan tentang perlindungan hukum bagi para pihak dalam transaksi internasional yang disesuaikan dengan media ini. Dengan mempertimbangkan bentuk peraturan di berbagai negara dan usulan institusi internasional. Negara seyogianya mengambil jalur dengan membuat undang-undang tambahan untuk memperluas penerapan perlindungan hukum bagi para pihak dalam transaksi internasional "ruang-nyata" kepada para pihak dalam transaksi internasional internet.

Diperlukan adanya implementasi lebih lanjut yang mencangkup perlindungan hukum bagi para pihak dalam transaksi internasional dengan mengadopsi prinsip-prinsip perlindungan para pihak dalam transaksi internasional $\mathrm{PBB}, \mathrm{OECD}$, dan praktik perlindungan hukum bagi para pihak dalam transaksi internasional di berbagai negara.

\section{Penutup}

Paparan di atas menunjukan bahwa para pihak dalam transaksi elektronik internasional berada pada posisi yang sangat lemah, maka diperlukan perlindungan hukum terhadap hak-hak para pihak. Perlindungan oleh negara dalam transaksi elektronik internasional tidak dapat diberikan oleh satu aspek hukum saja, melainkan oleh suatu perangkat hukum, sehingga terjadi persaingan yang jujur yang secara langsung atau tidak langsung akan menguntungkan para pihak dalam transaksi elektronik internasional. Dalam perspektif hukum, agenda ke depan yang dapat dilakukan dalam rangka memperkuat posisi tawar para pihak dalam transaksi elektronik internasional adalah dengan membuat kerangka perlindungan hukum bagi para pihak, agar para pihak dalam transaksi elektronik internasional dapat dilindungi hak-haknya.

Peranan negara yang dapat dilakukan terhadap perlindungan hukum bagi para pihak dalam transaksi elektronik internasional negara dengan cara: (1) Menghilangkan kendala-kendala hukum dan memberikan pengaturan dalam 
transaksi; (2) Memberikan fasilitas dalam bentuk pengaturan terhadap upaya perlindungan hukum bagi para pihak dalam transaksi internasional yang diberikan oleh pelaku usaha (self-regulation); dan (3) para pihak dalam transaksi internasional sendiri dalam melakukan transaksi. Diperlukan adanya keseragaman dalam memberikan perlindungan hukum bagi para pihak dalam transaksi internasional di berbagai negara. Sehingga model pengaturan yang mutlak diberikan oleh negara, yakni: pertama, harmonisasi hukum, dan Kedua, standarisasi Internasional.

\section{Daftar Pustaka}

Andrews, Rachelle, "Electronic Commerce: Lessons Learned From The European Legal Model", Intellectual Property Law Bulletin Spring (2005), 9 No. 2.

Alboukrek, Karen "Adapting to A New world of transaksi elektronik: The Need for Uniform Consumer Protection in the International Electronic Marketplace", George Washington International Law Review, 2003.

Asnawi, Haris Faulidi, Transaksi Bisnis transaksi elektronik Perspektif Islam, Magistra Insania Press, Yogyakarta, 2004.

Bainbridge, David, Introduction to Computer Law, 3 nd Edition, Pitman Publishing, Landon, 2006.

Barkatullah, Abdul Halim, Transaksi Konsumen dalam Bisnis e-Commerce, Nusa Media, Bandung, 2009.

Castles, Lance Politic dan Economic Behavior in Java: The Kudus Cigarette Industry, diterjemahkan oleh J. Sirait, Th. Sinar Harapan, 9 Jakarta, 2006.

Ferrera, Gerald R., et.al., Cyber Law Text and Cases, Thomson Learning, United States, 2010.

Juwana, Hikmahanto, Hukum Ekonomi dan Hukum Internasional, Lentara Hati, Jakarta, 2002.

Kamal, Farizal F., Cyber business, cet. 3, Elex Media Komputindo, Jakarta, 2009.

Kartohadiprodjo, Soediman, Tata Hukum di Indonesia, Cetakan ke-12, Ghalia Indonesia, Jakarta, 1993.

Laporan, OECD Forum on Electronic Commerce, Oktober 1999, di www.oecd.org/ dsti/sti/it/ec/act/pdf/forum_report.pdf. diakses 4 Agustus 2001.

Makarim, Edmon, Kompilasi Hukum Telematika, PT RajaGrafindo Persada, Jakarta, 2009. 
Masinambow, E.K.M., ed., Hukum dan Kemajemukan Budaya, Sumbangan Karangan Untuk Menyambut Hari Ulang Tahun ke-70 Prof. Dr. T.O. Ihromi, Yayasan Obor Indonesia, Jakarta, 2008.

Nasution, AZ. Hukum Perlindungan Konsumen, Diadit Media, Jakarta, 2006.

Nurhayati, Irna \& Dina Widyaputri Kariodimedjo, “Tantangan transaksi elektronik Bagi Hukum Bisnis Nasional", Mimbar Hukum Majalah FH UGM, Edisi Khusus No. 39/X/2001.

Ramli, Ahmad M., Cyber Law dan HAKI dalam Sistem Hukum Indonesia, Refika Aditama, Bandung, 2004.

Shidarta, Shidarta, Hukum Perlindungan Konsumen Indonesia, Edisi Revisi Grasindo, Jakarta, 2010.

Shofie, Yusuf, Perlindungan Para Pihak dalam Transaksi Internasional dan Instrumeninstrumen Hukumnya, PT. Citra Aditya Bakti, Bandung, 2003.

Soekanto, Soerjono dan Sri Mamudji, Penelitian Hukum Normatif, Rajawali Presss, Jakarta, 2004.

Sunggono, Bambang, Metode Penelitian Hukum, Rajawali Press, Jakarta, 2007.

Suparni, Niniek Masalah Cyberspace Problematika Hukum dan Antisipasi Pengaturannya Fortun Mandiri Karya, Jakarta, 2001.

Zain, Saami "Regulation of E-Commerce by Contract: is it Fair to Consumers?", The University of West Los Angeles (2007), 31 U. West. L.A. L. Rev. 163.

Zhao, Yun, Dispute Resolution in Electronic Commerce, Martinus Nijhoff Publishers, Leiden/Boston, 2009. 